\title{
Bearing Capacity Standards for Forest Roads Constructed Using Various Technologies from Mechanically and Chemically Stabilised Aggregate
}

\author{
Andrzej Czerniak, Sylwester M. Grajewski, Ewa E. Kurowska
}

\begin{abstract}
Forest roads are essential for adequate forest management and environmental protection. They enable tourism and recreation activity, while at the same time playing a very important role in fire protection. When open to the local traffic, they significantly supplement the public traffic networks. Costs of constructing permanent roads in forested areas are considerable, because they need to have adequate bearing capacity. Forest roads are predominantly constructed using natural or anthropogenic aggregate stabilised mechanically and chemically. A tangible parameter verifying the proper construction of road structure is provided by its bearing capacity, i.e. the capacity of the pavement to carry loads generated by traffic without excessive strains hindering normal use of the pavement or reducing its durability. Some forest road networks are also constructed as temporary roads composed of cheaper aggregates. It seems reasonable to assume different bearing capacity standards for such roads than for permanent roads.

The aim of the studies presented in this paper was to develop bearing capacity standards for forest roads constructed using various technologies. The adopted research hypothesis assumes that each of the analysed technologies is characterised by a different bearing capacity required during road construction inspections. An example of such a structure may be provided by the so-called geotextile mattress and crushed stone constructed on wetland soils. When developing the standards, the analyses included the predicted traffic intensity, assumed operation time before rehabilitation is required, soil conditions and the type of construction material.

Bearing capacity of the testing road sections was assessed based on values of strain moduli calculated from the static plate load tests (VSS). As a result, bearing capacity standards were obtained for structures constructed using aggregates and chemical stabilisers as well as geotextiles potentially facilitating reduction of the layer thickness without deterioration of road durability.
\end{abstract}

Keywords: quality control, bearing capacity standard, geotextile mattress, static plate load test

\section{Introduction}

At present, the forested area in Poland is 9447 thousand ha, which accounts for $30.9 \%$ forest cover (Raport 2018). In terms of the ownership structure, public forests predominate at $80.7 \%$, including forests administered by the State Forests National Forest Holding (SF NFH) accounting for $76.9 \%$.

Rational and multipurpose forest management requires an adequate condition of the road infrastructure.
Forest roads, by providing access to stands, not only facilitate appropriate utilisation of the production potential of forest complexes (Giefing 1991, Pieńkos 1994, Czerniak 2004a), but also significantly influence nonproductive functions of forests, including tourism and recreation (Paschalis 1997, Laurów 2004, Sławski and Sławska 2009, Janeczko 2008, Kikulski 2013, Czerniak et al. 2019). The density and technical condition of forest roads also affects the efficiency of operations related to forest protection and disaster control, particularly 
Table 1 Recommendations for VSS tests of bearing capacity tests in forest roads

\begin{tabular}{|c|c|c|}
\hline $\begin{array}{l}\text { Minimum measurement frequency } \\
\text { (according to PN-S-96023:1984) }\end{array}$ & Measurement method & $\begin{array}{l}\text { Assessment of measurement results } \\
\text { (according to OST D-05.02.01 1998) }\end{array}$ \\
\hline $\begin{array}{l}\text { Measurements need to be taken at } \\
\text { least once per } 3000 \mathrm{~m}^{2} \text { or according } \\
\text { to the recommendations of } \\
\text { construction engineer }\end{array}$ & $\begin{array}{l}\text { Measurements of bearing capacity pavement } \\
\text { need to be performed using a plate of } 300 \\
\text { mm in diameter in accordance with } \\
\text { BN-8931-02:1964 and PN-S-02205:1998 }\end{array}$ & $\begin{array}{l}\text { Minimum strain modulus after the } 1^{\text {st }} \text { and } 2^{\text {nd }} \text { loading cycles of } \\
\text { macadam pavement should be } 100 \text { and } 140 \mathrm{MN} \cdot \mathrm{m}^{-2} \text { for very light } \\
\text { and light traffic* }, 100 \text { and } 170 \mathrm{MN} \cdot \mathrm{m}^{-2} \text { for medium light and medium } \\
\text { traffic }{ }^{*} \text { at compaction estimated by deformation ratio } I_{0} \leq 2.2\end{array}$ \\
\hline
\end{tabular}

* - number of standardized axle passes (100 kN axle/lane/24h) in the mentioned traffic categories: very light <4, light 4-12, medium light 13-24, and medium 25-70 (Katalog... 1997)

fighting forest fires (Grajewski 2019, Grajewski and Czerniak 2019). Moreover, while bringing tangible benefits resulting from lowering overheads incurred for forest management operations, forest roads also facilitate the execution of required protection measures (Laurów 1995, Kubiak and Grodecki 1995, Porter 1995).

According to the data of SF NFH from 2015, its 430 forest districts administer a total of $106,640 \mathrm{~km}$ internal roads of various rank within the networks of forest transport areas - starting from trunk roads through byways and access roads up to service roads (Trzciński et al. 2016). Maintenance of such an excessive road network requires considerable financial outlays. Despite high expenditure incurred annually to improve the condition of the road infrastructure, the investment needs related to the construction, modernisation and repairs of road networks within forests continue to be huge and are connected with all forest road types. The necessary modernisation concerns first of all main roads combining the function of the so-called fire access roads with timber transport. In Poland, some forest roads have been included in the forest fire protection system and have been assigned minimum technical parameters by the provisions of industry and general law (Instrukcja... 1996, Rozporządzenie... 1999). These roads must have a certain bearing capacity, i.e. the capacity of the pavement to carry loads generated by traffic without producing excessive strains hindering normal pavement use or reducing its durability.

An objective quality assessment in the case of performed road works may be provided by the monitoring of bearing capacity parameters for the road pavement (Table 1). Bearing capacity of forest roads is most frequently tested based on the determination of strain moduli using a static plate test (VSS), while currently it is also increasingly using the Light Falling Weight Deflectometer test (LFWD).

\section{Aim of Study}

At present, in the construction of forest roads, the predominantly used technologies are based on aggre- gate produced by crushing solid rock. In the case of forest districts located at large distances from quarries, costs of transport of such materials are very high. For this reason, it is necessary to search for new innovative road construction technologies, which are less dependent on quarry aggregate as they use locally available materials, thus eliminating transport costs.

Forest road structures made from aggregate are rarely covered with asphalt or concrete and as a result the base course serves as a certain type of pavement. Since these pavements are water-permeable, the resulting plasticised subgrade promotes rapid rutting of these pavements. As a consequence, crushed stone roads serving as important transport traffic areas need to be frequently repaired, thus becoming costly to maintain.

A tangible parameter for the improvement of road structure is related to its bearing capacity, i.e. the capacity to carry external loads. The aim of this study was to develop standards for bearing capacity of forest roads constructed using various technologies. When developing these standards, the considered parameters included predicted traffic intensity, assumed serviceability with no need for rehabilitation, soil conditions and type of material used.

Studies were conducted on structures based on aggregates as well as chemical stabilisers and geotextiles potentially facilitating reduction of the layer thickness with no deterioration of road durability (e.g. Perkins 1999, Dewangan et al. 2013, Gradkowski 2014, Alenowicz 2015, Ingle and Bhosale 2017).

\section{Research hypotheses}

$\Rightarrow$ Application of innovative technological solutions promotes more rational, cost-effective use of aggregate in forest road construction

$\Rightarrow$ Each of the analysed technologies is characterised by a different bearing capacity required during road construction inspections

$\Rightarrow$ Despite adoption of different bearing capacity standards, these structures meet the requirements binding for forest roads. 


\section{Materials and Methods}

\subsection{Introduction to Research Methodology}

The static plate load test (VSS) consists of the measurement of vertical strains (settlement) of the subgrade or the layer(s) of the pavement generated when static loading applied on a steel plate is repeated twice. Between the two loading cycles performed at increments of $0.05 \mathrm{MN} \mathrm{m}^{-2}$ up to the required final value, the subgrade unloading process is executed at increments of 0.1 $\mathrm{MN} \mathrm{m}^{-2}$ (BN-8931-02:1964, PN-S-02205:1998).

Road pavement tests are typically conducted using a plate of $300 \mathrm{~mm}$ in diameter, onto which loading is exerted using a hydraulic servo-motor based on a counterbalance of considerable mass, exceeding considerably the exerted force (Wyroślak and Ossowski 2016).

In the course of VSS measurements for individual values of applied pressure (loading), the values of settlement are read and plotted producing a graph for analyses of strain in the tested surface. The final load reaches the maximum values (BN-8931-02:1964, PNS-02205:1998):

$\Rightarrow 0.25 \mathrm{MN} \mathrm{m}^{-2}$ in tests of natural subgrade or embankment

$\Rightarrow 0.35 \mathrm{MN} \mathrm{m}^{-2}$ in tests of upgraded subgrade

$\Rightarrow 0.45 \mathrm{MN} \mathrm{m}^{-2}$ in tests of structural pavement layers

$\Rightarrow 0.55 \mathrm{MN} \mathrm{m}^{-2}$ in tests of the entire pavement structure.

The obtained results are used to calculate values of strain modulus $E_{1}$ after the first surface loading cycle, strain modulus $E_{2}$ determined analogously in the $2^{\text {nd }}$, i.e. repeated loading cycle of that surface, as well as deformation ratio $I_{0}$. Additionally, values of permanent strain and resilient strain of the surface under the loading plate may also be determined. Strain moduli are calculated using an equation applied not only in Poland (PN-S-02205:1998), but also in other European countries such as Switzerland (SN 670317b:1998-01, SN 670312b:1998-04), Germany (DIN 18134:2012-04) or Great Britain (BS 5930:1981, Węgliński 2018):

$$
E_{\mathrm{i}}=\frac{3 \Delta p}{4 \Delta s} \times D
$$

Where:

$E_{\mathrm{i}} \quad$ strain modulus after the $1^{\text {st }}$ loading cycle $E_{1}$ or strain modulus after the $2^{\text {nd }}$ loading cycle $E_{2}$, $\mathrm{MN} \mathrm{m}^{-2}$

$\Delta p \quad$ increment in loads within the assumed range $\left(\Delta p=p_{0.15}-p_{0.05}\right.$ in case of dirt subgrade, $\Delta p=$ $=p_{0.25}-p_{0.15}$ for upgraded subgrade and structural layers, $\Delta p=p_{0.35}-p_{0.25}$ for the entire pavement structure), $\mathrm{MN} \mathrm{m}^{-2}$

$\Delta s$ increment in settlement corresponding to the increment in loading $\left(\Delta s=s_{0.15}-s_{0.05}\right.$ for dirt subgrade, $\Delta s=s_{0.25}-s_{0.15}$ for upgraded subgrade and structural layers, $\Delta s=s_{0.35}-s_{0.25}$ for the entire pavement structure), $\mathrm{mm}$

$D$ diameter of the load plate, $\mathrm{mm}$.

The value of the deformation ratio Io is calculated using Eq. (2).

$$
I_{0}=\frac{E_{2}}{E_{1}}
$$

At present, 4 types of static load plates are available: 3-point static load plates with analogue displacement sensors (3a), 3-point static load plates with electronic displacement sensors (3e), 1-point static load plates with analogue displacement sensors (1a) and 1-point static load plates with electronic displacement sensors (1e). This shows that, apart from the previously used VSS plates to measure settlement of the load plate in three peripheral points (according to BN8931-02:1964 and PN-S-02205:1998), other available apparatus may also measure the value of plate settlement in one central point of the plate. Electronic versions of 1-point load plates produced in Germany are equipped with software adapted to tests performed in accordance with the DIN 18134:2001-09 and DIN 18134:2012-04 standards.

Irrespective of the type of static plate used, the testing procedure remains the same. The only difference is that the mean value of the load plate settlement read from three sensors is calculated in the case of the 3-point apparatus, while in the case of the 1-point apparatus the settlement value is read directly from the sensor.

\section{Methodological requirements:}

$\Rightarrow$ testing time - measurement in one testing point of the pavement (maximum load of $0.55 \mathrm{MN} \mathrm{m}^{-2}$ ) in accordance with the standard takes minimum $1.5 \mathrm{~h}$, if reading at each loading step is not accompanied by surface strains exceeding $0.05 \mathrm{~mm}$ within a 2-minute interval. Maintenance of an adequate time interval between individual loading and unloading steps is crucial to ensure reliability of results (Mackiewicz and Krawczyk 2015)

$\Rightarrow$ maintenance of an adequately heavy counterweight - typically a loaded truck with an adequately large clearance facilitating installation of measurement apparatus at a position 
ensuring reliability of measurement results (Krawczyk et al. 2015)

$\Rightarrow$ necessary short-term closure of a given road section to vehicle traffic (Grajewski 2019).

Despite the above-mentioned inconveniences, the static load plate test continues to be a basic method assessing the appropriate execution of road construction works in Polish forests. At relatively low costs, it provides reliable data on the condition of the tested surface and quality of performed road construction works. Despite the fact that no guidelines have been developed to date for forest road construction in Poland specifying requirements for bearing capacity of pavements or catalogues of typical road structures, in this research method a highly significant aspect of its application is related to the evaluation of the obtained results thanks to their direct comparison to available recommendations typically concerning public roads (PN-S-96023:1984, Rolla 1985, Kamiński 2012, OST D-05.02.01 1998, PN-S-02205:1998, Katalog 2014a, $2014 b)$. The investor is guaranteed adequate durability and safety of the road structure when specific parameter values are recorded in the tests. When the results do not meet the adopted design values, repair works should be carried out.

\subsection{Research Methods Applied in Testing Road Sections}

Forest road construction technologies are typically based on the structures composed of several layers of aggregate. When no binder or geotextile is used, these structures are susceptible to damage when exposed to heavy vehicle traffic.

This study focused on structures based on aggregates as well as chemical stabilisers and geotextiles potentially facilitating the reduction of layer thickness with no deterioration of road durability. In this study, Portland cement and asphalt emulsion were used.

Layers of cement-stabilised soil are used as upgraded soil subgrades, while aggregates reinforced with cement constitute the base course. In forest road construction, compacted cement-soil layers are used as road pavements, pavements of fire airfields, shunting yards, parking lots and landings. Studies conducted at the Department of Forest Engineering, the Poznań University of Life Sciences, determined the chemical effect of cement-soil base courses on the forest environment (Czerniak 2004b, 2005, Czerniak and Kayzer 2006). Portland cement with no additives such as industrial waste was considered to be most suitable for the construction of forest roads.
Emulsion is a dispersion of small molecules of one liquid in another liquid, in this case asphalt in water. Emulsions contain $20-30 \%$ of water. Full strength is attained by a pavement after complete evaporation of water (and practically only then it may be considered operational). In forests, the asphalt emulsion reinforces the road structure through surface or deep stabilisation of the aggregate. Pavement parameters vary depending on the applied stabilisation method and incurred costs. At relatively low financial outlays, either existing or new road structures may be stabilised. An advantage of this technology is related to its rapid execution particularly when an existing road is modernised using crushed aggregate. Deep stabilisation requires the use of heavy road construction machines such as recyclers, either self-propelled or aggregated with power tractors.

Previous studies indicate that in forests the design thickness of crushed stone layers may be reduced using geotextiles, geomeshes and geogrids (e.g. Perkins 1999, Dewangan et al. 2013, Gradkowski 2014, Alenowicz 2015, Ingle and Bhosale 2017). The possibility of reducing the thickness of crushed aggregate layer concerns mainly the woven geosynthetics, and to a lesser extent the needle punched (non-woven) geotextiles. In contrast to cell geogrids, they may be installed fast and they are relatively cheap considering the potential savings related to the purchase and transport of aggregate. Geogrids are geomeshes with rigid, integral nodes, which, in comparison to other meshes, exhibit some unique properties (Fig. 1).

The analyses were conducted in 9 sections of forest roads differing in pavement structures and located in western and central Poland (Fig. 2, Table 2).

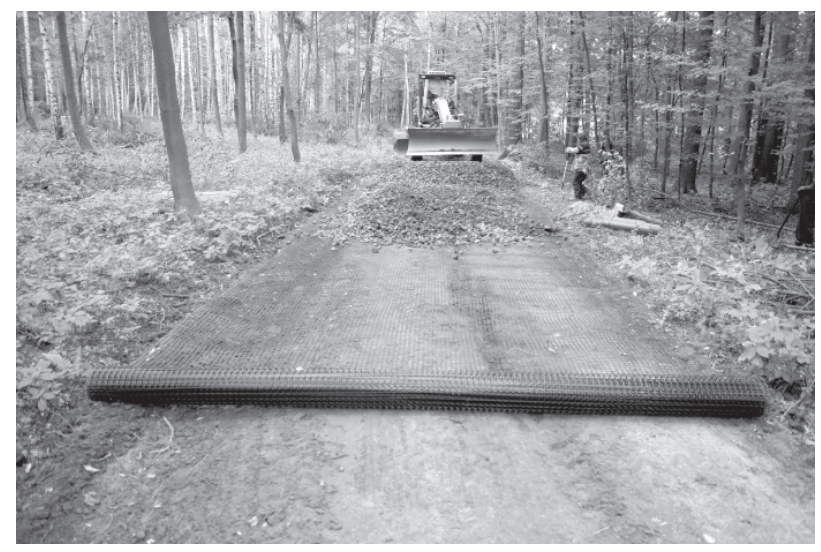

Fig. 1 A test of geogrid suitability for separating aggregate from subsoil - effect: saving $20 \%$ of aggregate in construction of forest fire roads (photo: A. Czerniak) 


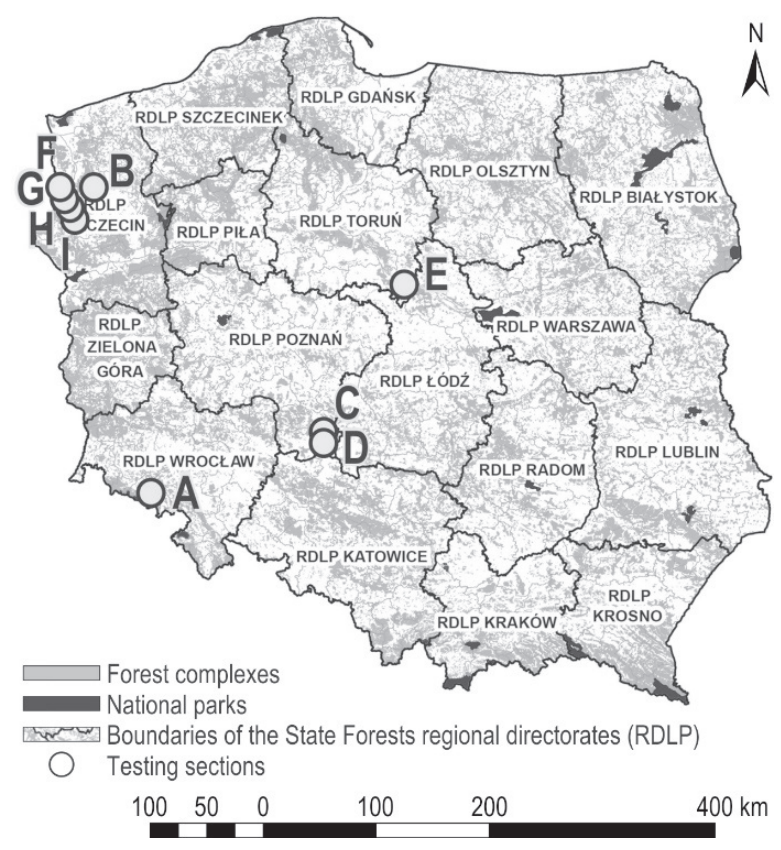

Fig. 2 Location of testing road sections (A-I) on afforestation map of Poland (afforestation map according to: State Forests Information Centre, 2018)
Bearing capacity was measured using static load plates (Fig. 3):

$\Rightarrow 1 \mathrm{e}-\mathrm{HMP}$ PDG Pro by Prüfgerätebau $\mathrm{GmbH}$, equipped with one electronic displacement sensor of the load plate of $300 \mathrm{~mm}$ in diameter

$\Rightarrow$ 3e - VSS-3P-000 7408 by MULTISERW-Morek, equipped with three electronic displacement sensors of the load plate of $300 \mathrm{~mm}$.

Irrespective of the pavement type, the static load plate tests were conducted in wheel tracks in accordance with the PN-S-02205:1998 standard, each time applying loads up to the final loading of max. $0.5 \mathrm{MN} \mathrm{m}^{-2}$ as in the case of testing the entire pavement structure. The measurement results were used to calculate values of strain modulus after the $1^{\text {st }}$ and $2^{\text {nd }}$ loading cycles ( $E_{1}$ and $\left.E_{2}\right)$, deformation ratio $I_{0}$ as well as values of permanent strains $P$ and resilient strains $R$ from the $1^{\text {st }}$ plate loading. Strain moduli after the $1^{\text {st }}$ and $2^{\text {nd }}$ loading were calculated following equation (1) assuming increment in plate displacement corresponding to the difference in loading of 0.25 and $0.35 \mathrm{MN} \mathrm{m}^{-2}$. Values of deformation ratio $I_{\mathrm{o}}$ were calculated according to Eq. (2).

Table 2 Characteristics of testing sections in which bearing capacity was measured

\begin{tabular}{|c|c|c|c|c|}
\hline SS & Delimitation ${ }^{1}$ & Description of pavement structure, subgrade and soil conditions & $\left|\begin{array}{c}\text { gwt } \\
{[\mathrm{m} \text { b.g.l. }]}\end{array}\right|$ & $G_{n}$ \\
\hline A & $\begin{array}{l}50.784809 N, 15.832848 \mathrm{E} \\
50.770108 N, 15.830542 \mathrm{E}\end{array}$ & $\begin{array}{l}0-1 \mathrm{~cm} \text { quarry aggregate } 0 / 4 \mathrm{~mm}, 1-16 \mathrm{~cm} \text { quarry aggregate } 4 / 31.5 \mathrm{~mm}, 16-81 \mathrm{~cm} \text { quarry aggregate } \\
0 / 63.0 \mathrm{~mm}, 81-100 \mathrm{~cm} \text { embankment for non-construction purposes } \mathrm{NN},>100 \mathrm{~cm} \text { host rock }\end{array}$ & - & G1 \\
\hline$B$ & $\begin{array}{l}53.865671 \mathrm{~N}, 15.449031 \mathrm{E} \\
53.873563 \mathrm{~N}, 15.477398 \mathrm{E}\end{array}$ & $\begin{array}{l}\text { 0-8 cm quarry aggregate } 0 / 31.5 \mathrm{~mm}, 8-24 \mathrm{~cm} \text { quarry aggregate } 0 / 63.0 \mathrm{~mm}, 24-64 \mathrm{~cm} \text { all-in aggregate } \\
\text { (separating layer), } 64-120 \text { all-in aggregate, }>120 \mathrm{~cm} \text { medium sand }\end{array}$ & - & G1 \\
\hline$C$ & $\begin{array}{l}51.166371 \mathrm{~N}, 18.085164 \mathrm{E} \\
51.165958 \mathrm{~N}, 18.084858 \mathrm{E}\end{array}$ & $\begin{array}{l}\text { 0-15 cm quarry aggregate } 0 / 31.5 \mathrm{~mm}, 15-28 \mathrm{~cm} \text { medium sand MSa in a woven geotextile semi-mattress or } \\
\text { on planar distributed woven geotextile, } 28-53 \mathrm{~cm} \text { medium sand MSa (drainage layer), } 53-73 \mathrm{~cm} \text { organic soil } \\
\text { Or, } 73-83 \mathrm{~cm} \text { silty clay siCl, } 83-113 \mathrm{~cm} \text { clayey sand clSa, }>113 \mathrm{~cm} \text { sandy clayey silt saclSi (Fig. 4) }\end{array}$ & 1.13 & G4 \\
\hline D & $\begin{array}{l}51.165958 \mathrm{~N}, 18.084858 \mathrm{E} \\
51.165591 \mathrm{~N}, 18.084456 \mathrm{E}\end{array}$ & $\begin{array}{l}\text { 0-15 cm medium sand MSa, } 15-30 \mathrm{~cm} \text { medium sand MSa in a woven geotextile semi-mattress or on } \\
\text { planar distributed woven geotextile, } 30-55 \mathrm{~cm} \text { medium sand MSa (drainage layer), } 55-85 \mathrm{~cm} \text { organic soil } \\
\text { Or, } 85-110 \mathrm{~cm} \text { sandy clay saCl, } 110-300 \mathrm{~cm} \text { clayey sand clSa (Fig. 4) }\end{array}$ & 1.08 & G4 \\
\hline $\mathrm{E}$ & $\begin{array}{l}52.570094 N, 19.133924 E \\
52.562999 N, 19.241465 E\end{array}$ & $\begin{array}{l}0-4 \mathrm{~cm} \text { double dressing with stone chippings } 2 / 5 \mathrm{~mm} \text { and } 8 / 11 \mathrm{~mm}, 4-12 \mathrm{~cm} \text { gravel } \mathrm{Gr} \text { or crushed limestone } \\
\text { 0/31.5 mm, 12-37 cm furnace slag mixed to crushed limestone or concrete destruct 16/31.5 mm to improve } \\
\text { grading, } 37-80 \mathrm{~cm} \text { embankment for non-construction purposes NN, } 80-300 \mathrm{~cm} \text { fine sand FSa }\end{array}$ & - & G1 \\
\hline $\mathrm{F}$ & $\begin{array}{l}53.310424 \mathrm{~N}, 14.548159 \mathrm{E} \\
53.310546 \mathrm{~N}, 14.549286 \mathrm{E}\end{array}$ & $\begin{array}{l}\text { 0-1 cm quarry aggregate } 0 / 8 \mathrm{~mm}, 1-13 \mathrm{~cm} \text { quarry aggregate } 0 / 31.5 \mathrm{~mm}, 13-28 \mathrm{~cm} \text { subsoil cement } \\
\text { stabilization in situ }\left(R_{\mathrm{m}}=2.5-5.0 \mathrm{MN} \mathrm{m}{ }^{-2}, 28-148 \mathrm{~cm} \text { silty sand siSa, } 148-250 \mathrm{~cm} \text { fine sand with clayey }\right. \\
\text { sand FSaclsa, } 250-300 \mathrm{~cm} \text { clayey sand clSa }\end{array}$ & - & G1 \\
\hline $\mathrm{G}$ & $\begin{array}{l}53.310546 \mathrm{~N}, 14.549286 \mathrm{E} \\
53.310631 \mathrm{~N}, 14.550380 \mathrm{E}\end{array}$ & $\begin{array}{l}\text { 0-1 cm quarry aggregate } 0 / 8 \mathrm{~mm}, 1-13 \mathrm{~cm} \text { quarry aggregate } 0 / 31.5 \mathrm{~mm}, 13-28 \mathrm{~cm} \text { subsoil cement } \\
\text { stabilization ex situ }\left(R_{\mathrm{m}}=2.5-5.0 \mathrm{MN} \mathrm{m}^{-2}\right), 28-130 \mathrm{~cm} \text { fine sand with clayey sand FSaclsa, } 130-300 \mathrm{~cm} \\
\text { fine sand FSa }\end{array}$ & - & G1 \\
\hline $\mathrm{H}$ & $\begin{array}{l}53.310743 \mathrm{~N}, 14.552542 \mathrm{E} \\
53.310772 \mathrm{~N}, 14.554843 \mathrm{E}\end{array}$ & $\begin{array}{l}0-1 \mathrm{~cm} \text { quarry aggregate } 0 / 8 \mathrm{~mm}, 1-13 \mathrm{~cm} \text { quarry aggregate } 0 / 31,5 \mathrm{~mm}, 13-28 \mathrm{~cm} \text { quarry aggregate 0/63 } \\
\mathrm{mm} \text {, bidirectional geogrid, } 28-43 \mathrm{~cm} \text { medium sand } \mathrm{MSa}, 43-250 \mathrm{~cm} \text { fine sand with clayey sand FSaclsa }\end{array}$ & - & G1 \\
\hline 1 & $\begin{array}{l}53.311490 \mathrm{~N}, 14.560688 \mathrm{E} \\
53.312494 \mathrm{~N}, 14.561926 \mathrm{E}\end{array}$ & $\begin{array}{l}\text { 0-1 cm quarry aggregate 0/8 mm, 1-23 cm aggregate mix (crushed gravel 0/31,5 mm, medium sand and } \\
\text { subsoil in proportion 10:7:5) cement (6\%) stabilization ex situ, 23-150 cm fine sand with clayey sand } \\
\text { FSaclsa, 150-250 cm fine sand with fine gravel fgrFSa }\end{array}$ & - & G1 \\
\hline
\end{tabular}

Legend: SS - symbol of road section, ${ }^{1}$ - geographical coordinates of road section beginning and end, gwt - depth of stabilized ground water table,

m b.g.l. - metres below ground level, Gn - Polish subgrade bearing capacity group 


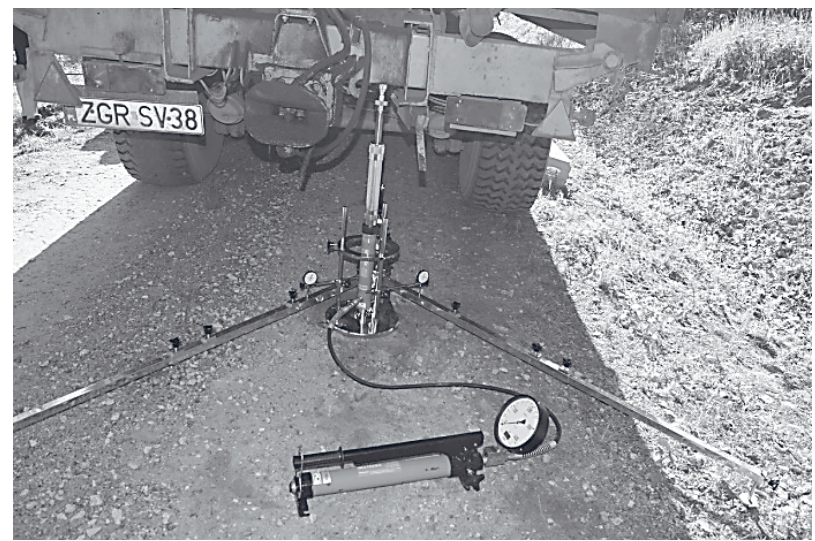

Fig. 3 Determination of bearing capacity in testing road sections with 3-point static load plate (VSS-3P-000 7408 MULTISERWMorek) (photo: A. Czerniak)

In the final development of standards (minimum values of the moduli) the following assumptions were adopted:

$\Rightarrow$ predicted traffic intensity in the designed forest road (very intensive, intensive, medium, low, very low)

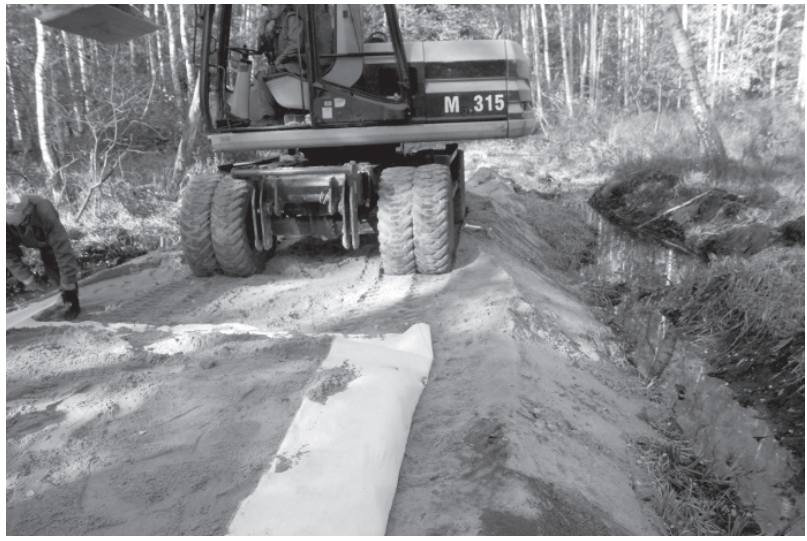

Fig. 4 An example of subgrade reinforcement using a woven geotextile and sand mattress in wetlands located in forests of Experimental Station, Poznań University of Life Sciences (photo: A. Czerniak)

$\Rightarrow$ serviceability with no need for repairs (20 years with no rehabilitation needed, 15 years with no rehabilitation needed, 10 years with no rehabilitation needed, temporary pavement)

$\Rightarrow$ soil conditions (good, bad)

$\Rightarrow$ type of material.

Table 3 Results of static load plate tests for bearing capacity of forest road pavements in testing

\begin{tabular}{|c|c|c|c|c|c|c|c|c|c|c|c|c|}
\hline \multirow{2}{*}{ SS } & \multirow[b]{2}{*}{$n$} & \multicolumn{3}{|c|}{$E_{1}, \mathrm{MN} \mathrm{m}^{-2}$} & \multicolumn{3}{|c|}{$E_{2}, \mathrm{MN} \mathrm{m}^{-2}$} & \multicolumn{3}{|c|}{$I_{0},-$} & \multicolumn{2}{|c|}{$0, \mathrm{~mm}$} \\
\hline & & $\begin{array}{c}\overline{\mathbf{x}} \\
\mathrm{X}_{\min }-\mathrm{X}_{\max }\end{array}$ & $M$ & SD & $\begin{array}{c}\overline{\mathbf{x}} \\
\mathrm{X}_{\min }-\mathrm{x}_{\max }\end{array}$ & M & SD & $\begin{array}{c}\overline{\mathbf{x}} \\
\mathrm{X}_{\min }-\mathrm{X}_{\max }\end{array}$ & $M$ & SD & $P$ & $R$ \\
\hline A & 13 & $\begin{array}{c}91 \\
35-141\end{array}$ & 82 & 33.60 & $\begin{array}{c}162 \\
75-281\end{array}$ & 161 & 53.38 & $\begin{array}{c}1.8 \\
1.3-2.3\end{array}$ & 1.7 & 0.34 & 0.73 & 0.93 \\
\hline B & 5 & $\begin{array}{c}42 \\
30-51\end{array}$ & 45 & 9.44 & $\begin{array}{c}106 \\
87-125\end{array}$ & 113 & 15.61 & $\begin{array}{c}\mathbf{2 . 7} \\
2.1-4.2\end{array}$ & 2.3 & 0.88 & 2.32 & 1.19 \\
\hline C & 4 & $\begin{array}{c}52 \\
42-59\end{array}$ & 53 & 8.88 & $\begin{array}{c}94 \\
75-125\end{array}$ & 89 & 24.16 & $\begin{array}{c}1.8 \\
1.6-2.1\end{array}$ & 1.8 & 0.22 & 1.23 & 1.55 \\
\hline$D$ & 10 & $\begin{array}{c}29 \\
15-47\end{array}$ & 30 & 9.56 & $\begin{array}{c}\mathbf{6 1} \\
27-94\end{array}$ & 71 & 23.15 & $\begin{array}{c}\mathbf{2 . 1} \\
1.3-3.0\end{array}$ & 2.1 & 0.49 & 3.07 & 2.08 \\
\hline$E$ & 9 & $\begin{array}{c}126 \\
64-188\end{array}$ & 141 & 41.95 & $\begin{array}{c}\mathbf{1 8 7} \\
153-225\end{array}$ & 188 & 21.13 & $\begin{array}{c}\mathbf{1 . 6} \\
1.1-2.4\end{array}$ & 1.4 & 0.49 & 0.57 & 0.69 \\
\hline$F$ & 10 & $\begin{array}{c}108 \\
79-188\end{array}$ & 96 & 33.05 & $\begin{array}{c}\mathbf{2 5 1} \\
153-375\end{array}$ & 229 & 73.11 & $\begin{array}{c}\mathbf{2 . 4} \\
1.6-4.5\end{array}$ & 2.4 & 0.83 & 0.75 & 0.54 \\
\hline G & 10 & $\begin{array}{c}199 \\
71-321 \\
\end{array}$ & 225 & 79.47 & $\begin{array}{c}\mathbf{4 0 8} \\
225-563\end{array}$ & 412 & 108.93 & $\begin{array}{c}\mathbf{2 . 4} \\
1.5-6.3 \\
\end{array}$ & 1.8 & 1.46 & 0.50 & 0.32 \\
\hline $\mathrm{H}$ & 10 & $\begin{array}{c}113 \\
63-225\end{array}$ & 102 & 44.00 & $\begin{array}{c}\mathbf{2 1 6} \\
147-375\end{array}$ & 225 & 61.62 & $\begin{array}{c}\mathbf{2 . 0} \\
1.3-3.7\end{array}$ & 2.0 & 0.65 & 0.68 & 0.58 \\
\hline 1 & 6 & $\begin{array}{c}190 \\
132-281\end{array}$ & 190 & 53.50 & $\begin{array}{c}\mathbf{4 2 9} \\
321-563\end{array}$ & 375 & 105.80 & $\begin{array}{c}\mathbf{2 . 4} \\
1.3-4.0\end{array}$ & 2.3 & 1.01 & 0.30 & 0.29 \\
\hline
\end{tabular}

Legend: $S S$ - symbol of road section; $\mathrm{n}$ - number of tests; $E_{1}$ - strain modulus after the $1^{\text {st }}$ loading cycle; $\overline{\mathbf{x}}, \mathrm{x}_{\min }, \mathrm{x}_{\max }-$ mean, minimum and maximum values $\mathrm{M}$ - median; $\mathrm{SD}$ - standard deviation; $E_{2}$ - strain modulus after the $2^{\text {nd }}$ loading cycle; $I_{0}$ - deformation ratio; 0 - permanent $P$ and resilient $R$ mean strain 


\section{Results}

Averaged values of strain modulus after the $1^{\text {st }}$ loading cycle $E_{1}$ on tested road sections ranged from 29 (section D) to 199 (section G) MN m ${ }^{-2}$ at minimum values within the range from 15 (section D) to 132 (sec- tion I) $\mathrm{MN} \mathrm{m}^{-2}$ and maximum values from 47 (section D) to 321 (section G) $\mathrm{MN} \mathrm{m}^{-2}$ (Table 3). Recording of higher values of moduli $E_{1}$ corresponds to increased variability of the results obtained in individual road sections, as results from a comparison of sections $B, C$, D with sections $\mathrm{G}$ and I (Table 3).
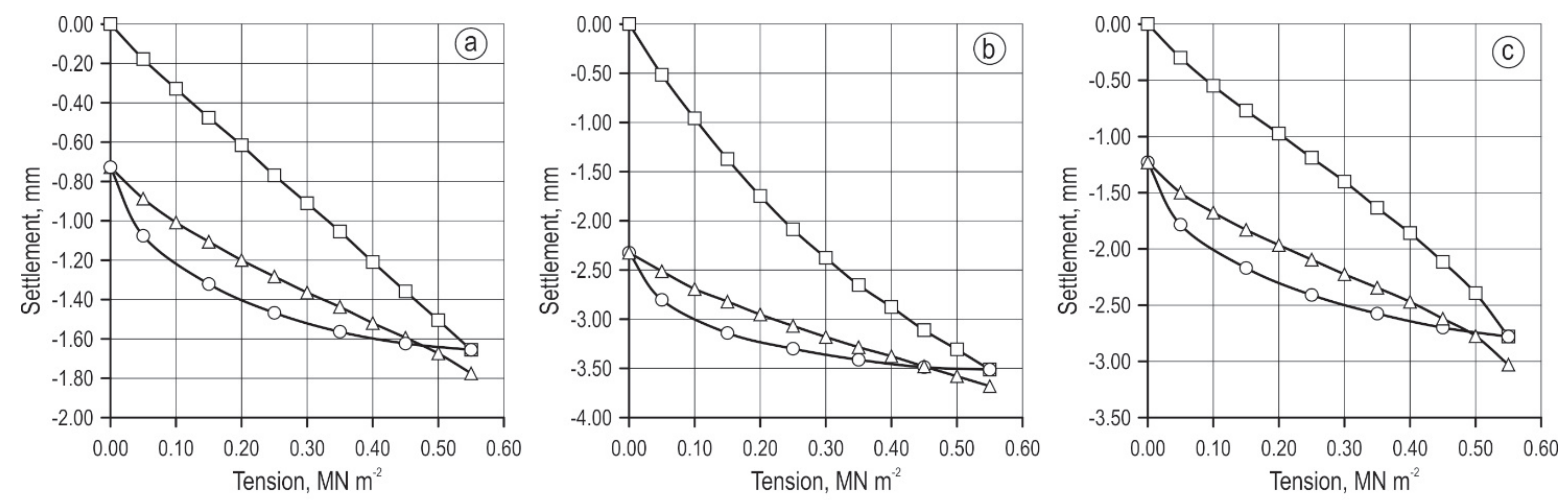

$\longrightarrow$ Load $1 \quad \longrightarrow$ Unload $\quad \longleftarrow$ Load 2
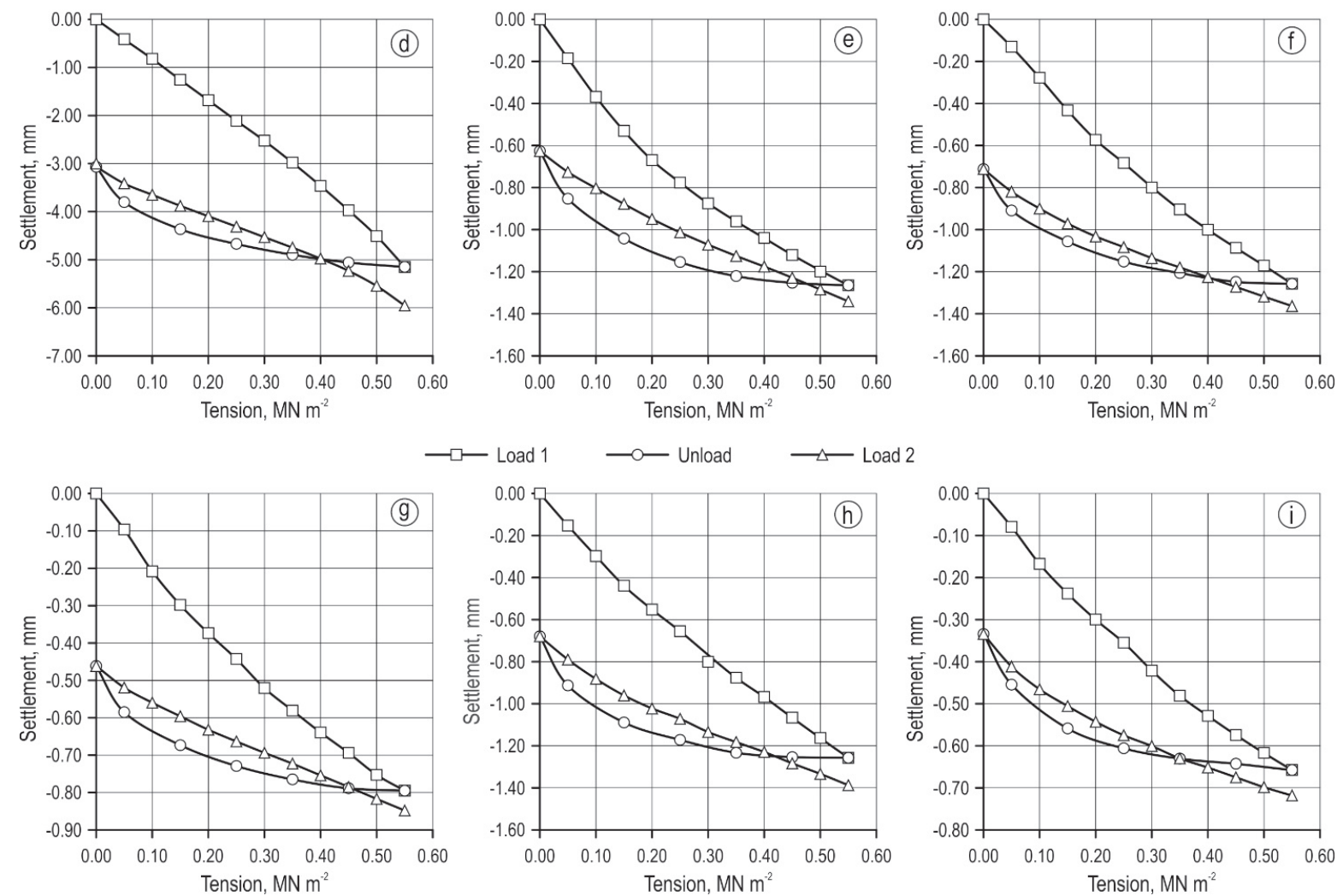

$\square$ Load $1 \quad \longrightarrow$ Unload $\longrightarrow$ Load 2
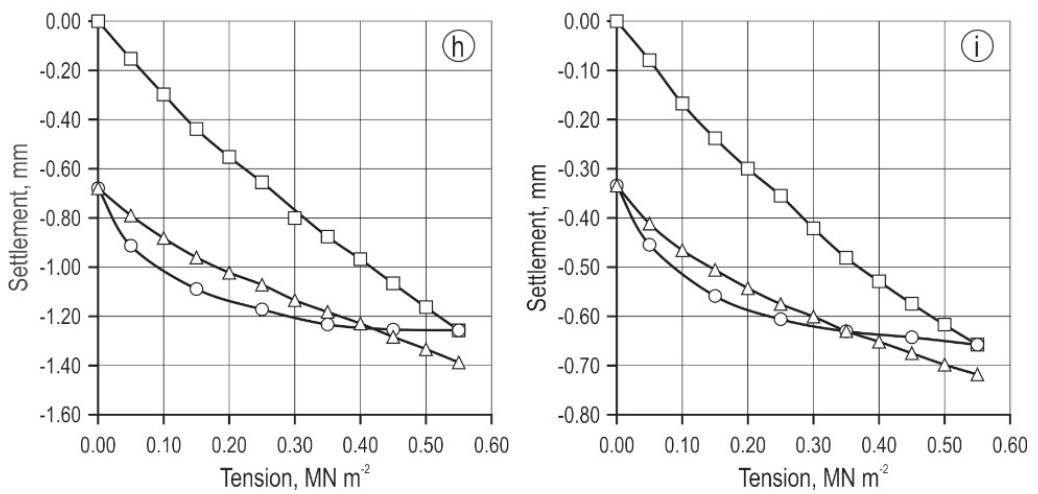

Fig. 5 Settlements and elastic recovery of tested pavements under influence of 2 static plate loading cycles: a) mountain quarry aggregate pavements (section A), b) lowland quarry aggregate pavement (section B), c) quarry aggregate pavement on subgrade of low bearing capacity reinforced with planar and semi-mattress woven geotextile (section C), d) sand pavement on low bearing capacity subgrade reinforced planar and semi-mattress woven geotextile (section D), e) crushed stone pavement with surface stabilisation with asphalt emulsion over a base course of old furnace slag road (section E), f) quarry aggregate pavement over a base course of sand stabilised with cement in situ (section F), g) quarry aggregate pavement over a base course of aggregate stabilised with cement ex situ (section G), h) quarry aggregate pavement over a base course reinforced with biaxial geogrid (section $\mathrm{H}$ ), i) pavement of a mixture of medium sand, crushed gravel $0 / 31.5 \mathrm{~mm}$ and native soil stabilised with cement ex situ (section I) 
Table 4 Proposed bearing capacity standards for forest roads in different technologies and diverse subgrades

Proposed bearing capacity standards for forest roads constructed using different technologies from aggregate stabilised mechanically and chemically Operation, design and repair assumptions

\begin{tabular}{|c|c|c|c|c|}
\hline \multirow[t]{2}{*}{$\begin{array}{l}\text { Predicted traffic }{ }^{*} \\
\text { Description of pavement structure, subgrade and soil conditions }\end{array}$} & \multicolumn{2}{|c|}{$\begin{array}{c}\text { Minimum values } \\
\text { of moduli } \\
\mathrm{MN} \mathrm{m}^{-2}\end{array}$} & \multirow[t]{2}{*}{$\begin{array}{c}\text { Service life } \\
\text { before rehabilitation } \\
\text { is required }\end{array}$} & \multirow[t]{2}{*}{ Remarks } \\
\hline & $E_{1}$ & $E_{2}$ & & \\
\hline 1 & 2 & 3 & 4 & 5 \\
\hline $\begin{array}{c}\text { Predicted traffic intensity - very intensive } \\
0-1 \mathrm{~cm} \text { quarry aggregate } 0 / 8 \mathrm{~mm}, 1-13 \mathrm{~cm} \text { quarry aggregate } 0 / 31.5 \mathrm{~mm}, 13-28 \\
\text { cm subsoil cement stabilization ex situ }\left(R_{\mathrm{m}}=2.5-5.0 \mathrm{MN} \mathrm{m}{ }^{-2}\right), 28-130 \mathrm{~cm} \text { fine } \\
\text { sand with clayey sand FSaclsa, } 130-300 \mathrm{~cm} \text { fine sand FSa }\end{array}$ & 200 & 410 & $\begin{array}{l}\mathbf{2 0} \text { years } \\
\text { (rehabilitation } \\
\text { required every } \\
10 \text { years) }\end{array}$ & $\begin{array}{c}\text { ex situ stabilisation with } \\
\text { Portland cement } 32.5 \mathrm{MN} \\
\mathrm{m}^{-2} \text { (8\% addition) } \\
\text { Subgrade - good conditions }\end{array}$ \\
\hline $\begin{array}{c}\text { Predicted traffic intensity - very intensive } \\
0-1 \mathrm{~cm} \text { quarry aggregate 0/8 mm, 1-23 cm aggregate mix (crushed gravel 0/31.5 } \\
\mathrm{mm} \text {, medium sand and subsoil in proportion 10:7:5) cement stabilization ex situ, } \\
23-150 \mathrm{~cm} \text { fine sand with clayey sand FSaclsa, } 150-250 \mathrm{~cm} \text { fine sand with fine } \\
\text { gravel fgrFSa }\end{array}$ & 190 & 430 & $\begin{array}{l}20 \text { years } \\
\text { (rehabilitation } \\
\text { required every } \\
10 \text { years) }\end{array}$ & $\begin{array}{l}\text { Optimal mixture stabilised ex } \\
\text { situ with Portland cement } \\
32.5 \mathrm{MN} \mathrm{m}^{-2} \text { (6\% addition) } \\
\text { Subgrade - good conditions }\end{array}$ \\
\hline $\begin{array}{c}\text { Predicted traffic intensity - intensive } \\
\text { 0-1 cm quarry aggregate 0/8 mm, 1-13 cm quarry aggregate 0/31.5 mm, 13-28 } \\
\mathrm{cm} \text { subsoil cement stabilization in situ }\left(R_{\mathrm{m}}=2.5-5.0 \mathrm{MN} \mathrm{m}{ }^{-2}\right), 28-148 \mathrm{~cm} \text { silty } \\
\text { sand siSa, } 148-250 \mathrm{~cm} \text { fine sand with clayey sand FSaclsa, } 250-300 \mathrm{~cm} \text { clayey } \\
\text { sand clSa }\end{array}$ & 110 & 250 & $\begin{array}{l}\mathbf{1 5} \text { years } \\
\text { (rehabilitation } \\
\text { required every } \\
5 \text { years) }\end{array}$ & $\begin{array}{l}\text { in situ stabilisation with } \\
\text { Portland cement } 32.5 \mathrm{MN} \\
\quad \mathrm{m}^{-2} \text { (8\% addition) } \\
\text { Subgrade - good conditions }\end{array}$ \\
\hline \begin{tabular}{|c|} 
Predicted traffic intensity - intensive \\
$0-1 \mathrm{~cm}$ quarry aggregate $0 / 8 \mathrm{~mm}, 1-13 \mathrm{~cm}$ quarry aggregate $0 / 31.5 \mathrm{~mm}, 13-28$ \\
cm quarry aggregate $0 / 63 \mathrm{~mm}$, bidirectional geogrid, $28-43 \mathrm{~cm}$ medium sand MSa, \\
$43-250$ fine sand with clayey sand FSaclsa
\end{tabular} & 110 & 220 & $\begin{array}{l}15 \text { years } \\
\text { (rehabilitation } \\
\text { required every } \\
5 \text { years) }\end{array}$ & $\begin{array}{l}\text { Structure reinforced with } \\
\text { geotextile } \\
\text { Subgrade - good conditions }\end{array}$ \\
\hline \begin{tabular}{|c} 
Predicted traffic intensity - medium \\
$0-4 \mathrm{~cm}$ double dressing with stone chippings $2 / 5 \mathrm{~mm}$ and $8 / 11 \mathrm{~mm}, 4-12 \mathrm{~cm}$ \\
gravel Gr or crushed limestone 0/31.5 mm, 12-37 cm furnace slag mixed to \\
crushed limestone or concrete destruct 16/31.5 mm to improve grading, $37-80 \mathrm{~cm}$ \\
embankment for non-construction purposes NN, 80-300 cm fine sand FSa
\end{tabular} & 130 & 190 & $\begin{array}{l}10 \text { years } \\
\text { (rehabilitation } \\
\text { required every } \\
5 \text { years) }\end{array}$ & $\begin{array}{l}\text { cheap limestone aggregate, } \\
\text { structure with no geotextile } \\
\text { reinforcement Subgrade } \\
\quad \text { - good conditions }\end{array}$ \\
\hline $\begin{array}{c}\text { Predicted traffic intensity - medium } \\
0-1 \mathrm{~cm} \text { quarry aggregate } 0 / 4 \mathrm{~mm}, 1-16 \mathrm{~cm} \text { quarry aggregate } 4 / 31.5 \mathrm{~mm}, 16-81 \\
\text { cm quarry aggregate 0/63.0 mm, } 81-100 \mathrm{~cm} \text { embankment for non-construction } \\
\text { purposes NN, }>100 \mathrm{~cm} \text { host rock }\end{array}$ & 90 & 160 & $\begin{array}{l}10 \text { years } \\
\text { (rehabilitation } \\
\text { required every } \\
5 \text { years) }\end{array}$ & $\begin{array}{l}\text { Structure with no geotextile } \\
\text { reinforcement } \\
\text { Subgrade - good conditions }\end{array}$ \\
\hline $\begin{array}{c}\text { Predicted traffic intensity - low } \\
0-8 \mathrm{~cm} \text { quarry aggregate 0/31.5 mm, 8-24 cm quarry aggregate 0/63.0 mm, } \\
24-64 \mathrm{~cm} \text { all-in aggregate (separating layer), } 64-120 \text { all-in aggregate, }>120 \mathrm{~cm} \\
\text { medium sand }\end{array}$ & 40 & 110 & $\begin{array}{l}10 \text { years } \\
\text { (annual maintenance } \\
\text { works required, } \\
\text { rehabilitation every } 5 \\
\text { years) }\end{array}$ & $\begin{array}{l}\text { Pavement from cheap } \\
\text { aggregate, no geotextile } \\
\quad \text { reinforcement } \\
\text { Subgrade - poor conditions }\end{array}$ \\
\hline $\begin{array}{c}\text { Predicted traffic intensity - very low } \\
0-15 \mathrm{~cm} \text { quarry aggregate } 0 / 31.5 \mathrm{~mm}, 15-28 \mathrm{~cm} \text { medium sand MSa in a woven } \\
\text { geotextile semi-mattress or applied on planar woven geotextile, } 28-53 \mathrm{~cm} \text { medium } \\
\text { sand MSa (drainage layer), } 53-73 \text { organic soil } 0 \mathrm{r}, 73-83 \mathrm{~cm} \text { silty clay siCl, 83-113 } \\
\text { cm clayey sand clSa, }>113 \mathrm{~cm} \text { sandy clayey silt saclSi }\end{array}$ & 50 & 90 & $\begin{array}{l}\text { Temporary } \\
\text { pavement } \\
\text { (highly frequent } \\
\text { maintenance works } \\
\text { needed) }\end{array}$ & $\begin{array}{l}\text { Marshy area, reinforced with } \\
\text { geotextile, } \\
\text { Subgrade - poor conditions }\end{array}$ \\
\hline $\begin{array}{c}\text { Predicted traffic intensity - very low } \\
0-15 \mathrm{~cm} \text { medium sand MSa, 15-30 medium sand MSa in a woven geotextile } \\
\text { semi-mattress or applied on planar woven geotextile, 30-55 medium sand MSa } \\
\text { (drainage layer), } 55-85 \mathrm{~cm} \text { organic soil } 0 \mathrm{r}, 85-110 \mathrm{~cm} \text { sandy clay saCl, } 110-300 \\
\text { cm clayey sand clSa }\end{array}$ & 30 & 60 & $\begin{array}{l}\text { Temporary } \\
\text { pavement } \\
\text { (highly frequent } \\
\text { maintenance works } \\
\text { needed) }\end{array}$ & $\begin{array}{l}\text { Marshy area, reinforced with } \\
\text { geotextile, pavement from } \\
\text { cheap aggregate } \\
\text { Subgrade - poor conditions }\end{array}$ \\
\hline
\end{tabular}

* Predicted traffic: very intensive - unlimited traffic of all vehicles is allowed, including heavy vehicles for wood transportation, regardless of humidity conditions; intensive- unlimited traffic of all vehicles is permissible, including heavy vehicles, mainly outside the periods of high moisture of the road surface and substrate; medium - unlimited traffic of medium-duty vehicles is allowed as well as occasional heavy-duty vehicle passing in all wet conditions; low - traffic of medium-duty vehicles is permissible, except for periods of high moisture of the road surface and substrate; very low - traffic of light-duty vehicles is permissible as well as occasional passing of rescue and fire-fighting vehicles 
Averaged values of strain modulus after the $2^{\text {nd }}$ loading cycle $E_{2}$ range from 61 (section D) up to 429 (section I) $\mathrm{MN} \mathrm{m}^{-2}$ at minimum values ranging from 15 (section D) to 321 (section I) $\mathrm{MN} \mathrm{m}^{-2}$, while maximum values were recorded within the range from 94 (section D) to 563 (sections G, I) $\mathrm{MN} \mathrm{m}^{-2}$. Similarly as in the case of modulus $E_{1}$, higher values of $E_{2}$ result in an increased variability of recorded results, as when comparing sections B, C, D with sections F, G, I (Table 3).

Averaged values of deformation ratio $I_{\mathrm{o}}$ range from 1.6 (section E) to 2.7 (section $\mathrm{B}$ ) at minimum values within the range from 1.1 (section $\mathrm{E}$ ) to 2.1 (section $\mathrm{B}$ ) and maximum values from 2.1 (section C) to 6.3 (section $\mathrm{G})$.

The highest mean values of permanent strains $P$ were recorded in sections $\mathrm{D}(3.07 \mathrm{~mm})$ and $\mathrm{B}(2.32 \mathrm{~mm})$, while the greatest resilient strains $R$ were observed in sections D $(2.08 \mathrm{~mm})$ and $C(1.55 \mathrm{~mm})$ in pavement structures, in which the subgrade with exceptionally low bearing capacity was reinforced using planar or half-mattress geotextile (Tables 2, 3, Fig. 5).

The tested road sections A, E, H were characterised by medium values of each analysed parameter.

The proposed bearing capacity standards for forest roads constructed using different technologies on diverse subgrades are presented in Table 4.

The traffic intensity observed on forest roads has not been uniform over the years. The roads destruction is mainly caused by logging and other forest works, and wood transportation by heavy vehicles. In Poland, forest works are planned for 10 -year periods. The adopted periods of use of roads constructed with divers technologies result from the management plans prepared for individual forest district. Less advanced technologies are used for 10 years, more expensive technologies for 15 and 20 years. Due to the fact that the traffic on forest roads is difficult to predict, and the condition of roads is additionally affected by changing weather conditions, it is necessary to make certain local design assumptions. The minimum values of the load-bearing modules proposed by the authors were adopted on the basis of many forest road audits carried out over the last 30 years.

\section{Discussion}

No guidelines have been developed for forest road construction in Poland concerning bearing capacity of pavements and no catalogues of typical road structures are currently available. Thus minimum criteria for bearing capacity of forest roads with flexible pave- ments may be adopted based on scattered information from various sources, mainly concerning public roads, as reported by:

$\Rightarrow$ Kamiński (2012), $E_{1} \geq 60 \mathrm{MN} \mathrm{m}^{-2}$ at $I_{\mathrm{o}} \leq 2.2$

$\Rightarrow$ Rolla (1985), $E_{1} \geq 75-100 \mathrm{MN} \mathrm{m}^{-2}$ (sufficient bearing capacity of pavements with light traffic load determined under least favourable testing conditions)

$\Rightarrow$ PN-S-96023:1984, $E_{2} \geq 140 \mathrm{MN} \mathrm{m}^{-2}$ (for macadam pavements in light traffic load category KR2)

$\Rightarrow$ general technical specification (OST D-05.02.01 1998), $E_{1} \geq 100 \mathrm{MN} \mathrm{m}^{-2}$ and $E_{2} \geq 140 \mathrm{MN} \mathrm{m}^{-2}$ at $I_{\mathrm{o}} \leq 2.2$ (for macadam pavements at very light and light traffic loads).

The insufficient bearing capacity of forest road pavements was already indicated in numerous studies (e.g. Kamiński and Czerniak 2001, 2003, Miler et al. 2008, Trzciński 2011, Grajewski 2019). The most common causes for the failure to reach adequate values of strain moduli indicated so far include:

$\Rightarrow$ low bearing capacity of subgrade

$\Rightarrow$ inadequate densification of structural layers of pavement and subgrade

$\Rightarrow$ inadequate selection of pavement structures for geotechnical conditions, e.g. excessively thin base course layers

$\Rightarrow$ interactions of the above-mentioned factors.

In the present study, very low values of bearing capacity parameters obtained for sections $C$ and $D$ result from extremely low bearing capacity of the marshy subgrade. The planned pavement structure was to provide serviceability of the previously completely unserviceable section of the forest road. In turn, a slightly higher bearing capacity of pavement in section $B$ results from insufficient densification of structural layers produced from unbound aggregates.

It needs to be emphasised here that the insufficient density of road pavements is unfortunately very common in the tested sections of forest roads. This promotes the development of linear deformations (rutting) altering the system of transverse profiles, and results in a deterioration of traffic safety, hinders adequate drainage of the pavement, while as a consequence leading to degradation of pavement structure and requiring urgent rehabilitation measures.

The presented results confirmed that ex situ stabilisation with hydraulic binders, by providing greater control over the process, results in increased effectiveness of this technology (sections G and I) compared to in situ stabilisation (section F). 
Obtained testing results also show that objectionable pavements produced from waste materials (in this case furnace slag) may be stabilised using asphalt emulsions following the prior soil gradation improvement in the pavement, at the same time producing the required minimum bearing capacity parameters of forest road pavements.

In view of the results of bearing capacity tests, it may be concluded that the application of geotextiles is an innovative solution reinforcing the structure and providing appropriate pavement durability. The use of geotextiles is not only limited to the construction of roads over weak subgrades with the simultaneous reduction of the amount of materials required to attain the necessary bearing capacity parameters (Perkins 1999, Leonardi and Buonsanti 2012, Dewangan et al. 2013, Gradkowski 2014, Alenowicz 2015, Ingle and Bhosale 2017). Traffic of heavy vehicles leads to a gradual accumulation of pavement damage (Ryś 2015), such as fatigue cracking of asphalt layers, permanent strain of subgrade, unbound layers of pavement structure and asphalt layers, fatigue cracking of the base course bound with hydraulic binder in the case of semi-rigid pavements as well as deterioration of pavement longitudinal levelling. The application of geotextiles enhances resistance to fatigue cracking in bituminous layers (Grabowski and Pożarycki 2007, 2008), while it may also delay and reduce pothole formation or rutting, facilitating considerable extension of pavement durability (Berg et al. 2000, Zhang and Hurta 2008, Al-Qadi et al. 2011, Calvarano et al. 2016). Therefore, costs related to road maintenance may be greatly reduced, while the serviceability of roads between successive rehabilitations may be significantly prolonged (Leonardi et al. 2012, 2020, Czerniak et al. 2013).

Currently, self-propelled road mixers or road mixers combined with tractors are increasingly used on forest roads. The efficiency of such machines on rutted aggregate roads is very high, and the costs are much lower than placing the next construction layer. These devices enable dosing both loose binders (e.g. cement) and asphalt emulsions to the aggregate. After agitating the aggregate to a depth of $20-30 \mathrm{~cm}$ and mixing it in order to obtain a homogenized mixture, it is necessary to shape and compact it. Even better results are achieved on the newly built roads. Appropriate (in situ) mixing of aggregate with stabilizer is cheaper than doing it in far-away plants, and the obtained bearing capacity is uniform over the entire road section. The use of such machines makes it much easier to obtain the bearing capacity for surfaces with emulsion and cement, as proposed in the article.

\section{Conclusions}

It was confirmed that roads constructed using the analysed technologies (observing technological accuracy) exhibit varying bearing capacity determined when commissioning the road works. This means that individual technological variants need to be ascribed different bearing capacity standards, ensuring the assumed durability of the pavement structure.

Some forest road networks consist of temporary roads constructed from cheaper aggregates. For such roads, it seems reasonable to adopt different bearing capacity standards during final acceptance of works. Although these roads require more frequent rehabilitation, they are much cheaper.

In the case of roads constructed on soils of low bearing capacity, e.g. wetlands, the so-called geotextile mattress and semi-mattresses are effective. Studies showed that they are elastic structures and, although the bearing capacity recorded during tests was not high, such pavements may be sufficient for necessary periodical forest management operations at limited traffic intensity.

Bearing capacity tests showed that the application of geotextiles is effective particularly for soils of low bearing capacity, even marshy soils. By incorporating woven geotextiles and geogrids into road structure, their construction costs may be reduced (especially in areas located at very large distances from aggregate quarries), while simultaneously satisfying binding requirements for forest roads.

\section{Acknowledgements}

The publication is co-financed within the framework of Ministry of Science and Higher Education programme as »Regional Initiative Excellence « in years 2019-2022, project number 005/RID/2018/19.

\section{References}

Alenowicz, J., 2015: Design of road pavements with aggregate layer stabilized with geosynthetic. Inżynieria Morska i Geotechnika 5: 760-767.

Al-Qadi, I.L., Dessouky, S., Tutumluer, E., Kwon, J., 2011: Geogrid mechanism in low-volume flexible pavements: accelerated testing of full-scale heavily instrumented pavement sections. International Journal of Pavement Engineering 12(2): 121-135. https://doi.org/10.1080/10298436.2010.535534

Berg, R.R., Christopher, B.R., Perkins, S., 2000: Geosynthetic reinforcement of the aggregate base/subbase courses in pavement structures. GMA White Paper II. Geosynthetic Materials Association, USA. 
BN-8931-02:1964 Drogi samochodowe. Oznaczanie modułu odkształcenia nawierzchni podatnych i podłoża przez obciążenie płytą. Polish standard.

BS 5930:1981 Code of practice for site investigations. British Standards Institution.

Calvarano, L.S., Palamara, R., Leonardi, G., Moraci, N., 2016: Unpaved road reinforced with geosynthetics. Procedia Engineering 158: 296-301. https://doi.org/10.1016/j.proeng.2016.08.445

Czerniak, A., (ed.), 2019: Turystyka i rekreacja w lasach Państwowego Gospodarstwa Leśnego Lasy Państwowe na przykładzie Dolnego Śląska. Wydawnictwo Naukowe Bogucki, Poznań, Poland.

Czerniak, A., (ed.), Grajewski, S.M, Kamiński, B., Miler, A.T., Okoński, B., Leciejewski, P., Trzciński, G., Madaj, A., Bańkowski, J., Wojtkowski, K., 2013: Wytyczne prowadzenia robót drogowych w lasach. OR-W LP w Bedoniu, Bedoń, Poland.

Czerniak, A., 2004a: Nośność cementowogruntowych dróg leśnych. PTPN, Wydz. Nauk Roln. i Leśn., Prace Kom. Nauk Roln. i Kom. Nauk Leśn. 96: 117-129.

Czerniak, A., 2004b: Zanieczyszczenie i bioindykacja stref ekotonowych lasu mieszanego świeżego (LMśw) w zasięgu oddziaływania cementowo-gruntowych podbudów dróg. Scientific Dissertations Series, 357, AR, Poznań, Poland.

Czerniak, A., 2005: The influence of road cement foundations on soil reaction of the fresh mixed forest. Infrastructure and Ecology of Rural Areas 3: 19-33.

Czerniak, A., Kayzer, D., 2006: Bioindication of forest ecotonal zones within the impact of cement-ground roads on the basis physical properties of Scots pine (Pinus sylvestris L.) needles. Sylwan 150(5): 59-67. https://doi.org/10.26202/sylwan.2005048

Dewangan, A., Gupta, D.P., Bakshi, R.K., Manchiryal, R.K., 2013: The significance of geotextile in unpaved roads with special reference to stress analysis. International Journal of Current Engineering and Technology 3(1): 168-178.

DIN 18134:2001-09: Determining the deformation and strength characteristics of soil by the plate loading test. Deutsches Institut für Normung e.V., Berlin, Germany.

DIN 18134:2012-04 Soil: Testing procedures and testing equipment. Plate load test. Beuth Verlag. Germany, https:// doi.org/10.31030/1869979

Giefing, D.F., 1991: Wpływ technologii pozyskania i transportu drewna w cięciach przedręb-nych na szkody i jakość techniczną pozostających drzewostanów sosnowych. In: A. Szujecki (ed.) Reakcja ekosystemów leśnych i ich elementów składowych na antropopresję (p. 77-86). Wyd. SGGW-AR, Warszawa, Poland.

Grabowski, W., Pożarycki, A., 2007: An evaluation of asphalt pavement reinforcement with geocomposite and geogrid. $4^{\text {th }}$ International Conference on Bituminous Mixtures and Pavements, 19-20 April, Thessaloniki, Greece: 701-710.
Grabowski, W., Pożarycki, A., 2008: Energy absorption in large dimension asphalt pavement samples reinforced with geosynthetics. Foundations of Civil and Environmental Engineering 11: 17-28.

Gradkowski, K., 2014: Planarne zbrojenia podłoży nawierzchni drogowych. Drogownictwo 9: 306-308.

Grajewski, S.M., 2019: Functionality of forest fire roads in view of requirements of modern fire engines and pumper trucks and currently used forest firefighting tactics and technologies. Scientific Dissertations Series, 511, Wyd. UPP, Poznań, Poland.

Grajewski, S.M., Czerniak, A., Szóstakowski, P., 2019: Features and performance of forest fire access roads and fire department connections as assessed by employees of the Polish State Fire Service. Safety \& Fire Technology 53(1): 68-87. https://doi.org/10.12845/sft.53.1.2019.4

Ingle, G.S., Bhosale, S.S., 2017: Full-scale laboratory accelerated test on geotextile reinforced unpaved road. Int. J. of Geosynth. and Ground Eng. 3(4): 33-45. https://doi. org/10.1007/s40891-017-0110-x

Instrukcja ochrony przeciwpożarowej obszarów leśnych, 1996: Dyrekcja Generalna Lasów Państwowych, Warszawa, Poland.

Janeczko, E., 2008: Possibilities in landscape design in context of social needs and preferences. Studia i Materiały CEPL w Rogowie 10, 3(19): 130-138.

Kamiński, B., 2012. Badania techniczne dróg leśnych. In: K. Jodłowski, A. Czerniak (eds.) Nowoczesne technologie budowy dróg, mostów i przepustów leśnych. Postępy Techniki w Leśnictwie 119: 47-51.

Kamiński, B., Czerniak, A., 2001: Wpływ podłoża gruntowego na nośność nawierzchni tłuczniowych. Prace Kom. Nauk Roln. i Kom. Nauk Leśn., Wydz. Nauk Roln. i Leśn., PTPN 90: 47-59.

Kamiński, B., Czerniak, A., 2003: Zastosowanie geokraty komórkowej do wzmacniania gruntowej drogi leśnej na podłożu spoistym. In: A.T. Miler (ed.) Kształtowanie i ochrona środowiska leśnego (p. 478-486). AR w Poznaniu, Poznań, Poland.

Katalog typowych konstrukcji nawierzchni podatnych i półsztywnych, 1997. Załącznik do Zarządzenia nr 6 Generalnego Dyrektora Dróg Publicznych z dnia 24 kwietnia 1997 r. Generalna Dyrekcja Dróg Publicznych, Warszawa, Poland.

Katalog typowych konstrukcji nawierzchni podatnych i półsztywnych, 2014a: Załącznik do Zarządzenia nr 31 Generalnego Dyrektora Dróg Krajowych i Autostrad z dnia 16 czerwca 2014 r. Generalna Dyrekcja Dróg Krajowych i Autostrad, Warszawa, Poland.

Katalog typowych konstrukcji nawierzchni sztywnych, 2014b: Załącznik do Zarządzenia nr 30 Generalnego Dyrektora Dróg Krajowych i Autostrad z dnia 16 czerwca 2014 r. Generalna Dyrekcja Dróg Krajowych i Autostrad, Warszawa, Poland. 
Kikulski, J., 2013: Społeczna ocena komunikacyjnego udostępnienia lasów do celów rekreacyjnych i turystycznych. Studia i Materiały CEPL w Rogowie 15, 37(4): 162-169.

Krawczyk, B., Mackiewicz, P., Szydło, A., 2015: Influence analysis of counterweight type used in static plate test on identified parameters of pavement courses and subgrade. Roads and Bridges 14(2): 143-157. https://doi.org/10.7409/ rabdim.015.010

Kubiak, M., Grodecki, J., 1995: Szlaki zrywkowe - ich znaczenie i zasady zakładania. In: K. Pieńkos (ed.) Proekologiczne i produkcyjne funkcje szlaków operacyjnych we współczesnej gospodarce leśnej (p. 22-25). Fundacja »Rozwój SGGW «, Warszawa, Poland.

Laurów, Z., 1995: Rola szlaków zrywkowych w warunkach górskich. In: K. Pieńkos (ed.) Proekologiczne i produkcyjne funkcje szlaków operacyjnych we współczesnej gospodarce leśnej (p. 26-30). Fundacja »Rozwój SGGW«, Warszawa, Poland.

Laurów, Z., 2004: Sport i turystyka a kondycja leśnictwa. Przegl. Leśn. 2: 28-29.

Leonardi, G., Buonsanti, M., 2012: FEM analysis of airport flexible pavements reinforced with geogrids. Adv. Sci. Let. 13(1): 392-395. https://doi.org/10.1166/asl.2012.3765

Leonardi, G., Buonsanti, M., Scopelliti, F., 2012: Theoretical and computational analysis of airport flexible pavements reinforced with geogrids. In $7^{\text {th }}$ RILEM International Conference on Cracking in Pavements, RILEM Bookseries 4: 12191227.

Leonardi, G., Lo Bosco, D., Palamara, R., Suraci, F., 2020: Finite element analysis of geogrid-stabilized unpaved roads. Sustainability 12(5): 1929. https://doi.org/10.3390/su12051929

Mackiewicz, P., Krawczyk, B., 2015: Influence of loading time on subgrade parameters derived from VSS static plate test. Roads and Bridges 14(1): 19-29. https://doi.org/10.7409/rabdim.015.002

Miler, A.T., Kamiński, B., Czerniak, A., Grajewski, S.M., Okoński, B., Stasik, R., Drobiewska, E., Krysztofiak, A., Poszyler-Adamska, A., Korżak, M., 2008: Ochrona obszarów mokradłowych na terenach leśnych. UPP, Poznań, Poland.

OST D-05.02.01, 1998: Ogólna Specyfikacja Techniczna. Nawierzchnia tłuczniowa. GDDP, Warszawa. Polish standard.

Paschalis, P., 1997: Założenia do zasad użytkowania lasu w koncepcji trwałego i zrównoważonego gospodarowania lasami. Sylwan 141(1): 49-56.

Perkins, S.W., 1999: Mechanical response of geosyntheticreinforced flexible pavements. Geosynthetics International 6(5): 347-382. https://doi.org/10.1680/gein.6.0157

Pieńkos, K., 1994: Badania wpływu wybranych czynników warunkujących stabilizację cementem gruntowych dróg leśnych. Rozpr. Nauk. Monogr. SGGW-AR, 192. Wyd. SGGW-AR, Warszawa, Poland.
PN-S-02205:1998: Drogi samochodowe. Roboty ziemne. Wymagania i badania. Polish standard.

PN-S-96023:1984: Konstrukcje drogowe. Podbudowa i nawierzchnia z tłucznia kamiennego. Polish standard.

Porter, B., 1995: Udostępnianie drzewostanów szlakami zrywkowymi. In: K. Pieńkos (ed.) Proekologiczne i produkcyjne funkcje szlaków operacyjnych we współczesnej gospodarce leśnej (p. 57-63). Fundacja »Rozwój SGGW«, Warszawa, Poland.

Raport o stanie lasów w Polsce 2017, 2018: State Forests Information Centre, Warsaw, Poland.

Rolla, S., 1985: Badania materiałów i nawierzchni drogowych. WKŁ, Warszawa, Poland.

Rozporządzenie Ministra Ochrony Środowiska, Zasobów Naturalnych i Leśnictwa z 16 sierpnia 1999 r. w sprawie szczegółowych zasad zabezpieczenia przeciwpożarowego lasów (Dz. U. z 1999 r., nr 73, poz. 824).

Ryś, D., 2015: Obciążenie dróg przez pojazdy ciężkie i ich wpływ na trwałość zmęczeniową konstrukcji nawierzchni podatnych i półsztywnych. Doctoral thesis, Politechnika Gdańska, Gdańsk, Poland.

SFIC, 2018: The State Forests in figures 2018. State Forests Information Centre, Warsaw, Poland.

Sławski, M., Sławska M., 2009: Las jako miejsce wypoczynku i rekreacji - analiza oczekiwań społecznych na przykładzie gminy Rogów. Studia i Materiały CEPL w Rogowie 11, 4(23): 140-150.

SN 670312b:1998-04 VSS. Gerät für den Plattendruckversuch $\mathrm{E}_{\mathrm{v}}$ und $\mathrm{M}_{\mathrm{E}}$.

SN 670317b:1998-01 Subgrade. Plate-loading test $E_{v}$ and $M_{E}$.

Trzciński, G., 2011: Analysis of technical parameters of forest roads in terms on timber haulage by high-tonnage vehicles. Wyd. SGGW, Warszawa, Poland.

Trzciński, G., Czerniak, A., Grajewski, S.M., 2016: The functioning of forest communication infrastructure. Infrastructure and Ecology of Rural Areas II/2: 527-542. https://doi. org/10.14597/infraeco.2016.2.2.037

Węgliński, S., 2018: Determination of load action ranges in static and dynamic tests of subgrades by applying rigid plates. Roads and Bridges 17(1): 73-88. https://doi. org/10.7409/rabdim.018.005

Wyroślak, M., Ossowski, R., 2016: Evaluation of deformation moduli in controlled soil embankment based on VSS plate and LFWD plate. Acta Sci. Pol. Architectura 15(3): 111-118.

Zhang, J., Hurta, G., 2008: Comparison of geotextile and geogrid reinforcement on unpaved road. Conference paper in Geotechnical Special Publication with 34 GeoCongress: Geosustainability and Geohazard Mitigation. GSP, 178. New Orleans, Louisiana, March 9-12. 
Authors' addresses:

Prof. Andrzej Czerniak, PhD

e-mail: andrzej.czerniak@up.poznan.pl

Sylwester M. Grajewski, PhD *

e-mail: sylwester.grajewski@up.poznan.pl

Ewa E. Kurowska, PhD

e-mail: ewa.kurowska@up.poznan.pl

Poznań University of Life Sciences

Faculty of Forestry and Wood Technology

Department of Forest Engineering

Wojska Polskiego 71C

60-625 Poznań

Received: May 19, 2020

POLAND

Accepted: September 12, 2020

* Corresponding author 